\title{
Physico-chemical and mechanical thermo-rheological characterization of three varieties of triticale starches
}

\author{
Z.N. Correa-Pacheco* \\ ${ }^{1}$ CONACYT-Centro de Desarrollo de Productos Bióticos, Instituto Politécnico Nacional \\ Yautepec, 62731, Morelos, México \\ P.A. González-Fuentes, C.L. Tramón-Pregnan \\ ${ }^{2}$ Departamento de Agroindustrias de la Facultad de Ingeniería Agrícola de la Universidad de Concepción \\ Chillán, 3812120, Chile \\ S.C. Solorzano-Ojeda \\ Centro de Investigación en Química Aplicada \\ Saltillo, 25294, Coahuila, México \\ A. Zúñiga-Quintana \\ Centro de Investigación de Polímeros Avanzados (CIPA) \\ Concepción, 4051381, Chile \\ M.A. Sabino Gutiérrez \\ Department of Chemistry, B5IDA Group, Universidad Simón Bolívar \\ Caracas, 1080A, Venezuela \\ J.L. Jiménez-Pérez \\ Unidad Profesional Interdisciplinaria en Ingenierías y Tecnologías Avanzadas-Instituto Politécnico Nacional \\ Gustavo A. Madero, 07340, Ciudad de México, México
}

(Received: September 20 ${ }^{\text {th }}$, 2018; Accepted: June 3rd, 2019)

\begin{abstract}
Nowadays, starch is an excellent biodegradable option instead of synthetic polymers, to avoid contamination. In this work, triticale starch from three varieties (Faraón, Peteroa and Aguacero) was isolated and the physico-chemical and thermo-rheological properties were evaluated. Also, mechanical properties of thermoplastic films using this starch were assessed. From the physico-chemical analysis it was found that the moisture, protein and lipids contents were slightly different among starches. Amylose value was similar. Thermo-rheological behavior measured by Mixolab ${ }^{\circledR}$ revealed that initial water uptake was higher for Faraón variety due to the grain morphology observed by Scanning Electron Microscopy (SEM). Values for gelatinization temperature obtained were $82.2{ }^{\circ} \mathrm{C}$ for Faraón starch, followed by Peteroa $\left(72.0{ }^{\circ} \mathrm{C}\right.$ ) and finally Aguacero $\left(65.6^{\circ} \mathrm{C}\right)$. From the mechanical properties, Faraón thermoplastic starch (TPS) films showed the highest value of Young's modulus $(1.90 \pm 1.09 \mathrm{MPa}$ ) for the composition 50/25/25 (starch/glycerol/water). The highest elongation at break $(64.77 \pm 14.14 \%)$ was obtained for Peteroa composition 50/35/15 (starch/glycerol/water). Then, triticale mainly used to feed animals more than for human consumption, could be good alternative for preparing biodegradable films with potential applications in agriculture and food packaging.
\end{abstract}

\section{Introduction}

Nowadays, an effort has been made to use biodegradable polymers for natural sources. Natural biopolymers come from four main sources: animal, seafood, agricultural and microbial [1].

Starch, is a polysaccharide that has been used as a raw material for production of biomaterials for applications in agriculture and food because of its low cost, availability, good tensile strength, and it is derived from a renewable resource [2].

Triticale ( $X$ triticosecale Wittmack) is a cereal grain of selfing, obtained artificially by humans from crossing wheat with rye. Its name is a combination of prefix Tritico (derived from Triticum) and the suffix Secale, the genera of the botanical parent plants. This is a cereal that adapts to any climate even more than wheat. It has a high starch content between $57 \%$ and $65 \%$, which gives it great potential for applications as forage and as a biomaterial [3-5].

Due to the agri-food potential of the triticale crop, INIA (Institute of Agricultural Research, Chile), through its regional research centers, has developed a series of new varieties of triticale, among them Aguacero, Faraón and Peteroa.

Many studies have been done related to starch quality determination [6]. However, for triticale starch, there are few information about rheological properties. Among new equipment for rheological characterization, Mixolab ${ }^{\circledR}$ has been used to determine the thermo-rheological properties of starches [7], replacing conventional instruments with the advantage of having information about protein weakening, starch gelatinization and retrogradation in only one test [8]. 
Different films based on thermoplastic starches such as corn [9], potato [10], cassava [11] and wheat [12], have been elaborated and characterized. However, other sources of starch different than foodstuffs have been sought. For example: banana [13], tapioca [14] or mango [15], among others. Triticale as a new source of starch could be a good alternative for film preparation. Morphological, crystalline structure and thermal properties for triticale starch films were characterized in a previous work [5]. However, thermorheological and mechanical properties were not evaluated.

The aim of this work was to evaluate the physico-chemical properties and thermo-rheological behavior of Aguacero, Faraón and Peteroa triticale starch varieties and to report mechanical properties of this starch as a new source for biodegradable polymeric films with potential applications in packaging.

\section{Materials and methods}

Triticale grains from Aguacero, Faraón and Peteroa varieties Downpour-INIA, were provided by INIAQuilamapu, Chile. Glycerol was bought to Wrinkler.

\section{Starch isolation}

The extraction method using a pretreatment with temperature was used for starch isolation [16-18]. In brief: $300 \mathrm{~g}$ of starch was washed with cold water and mixed with $600 \mathrm{~mL}$ of water at $50{ }^{\circ} \mathrm{C}$ during $48 \mathrm{~h}$ with the incorporation of $\mathrm{SO}_{3}(0.2 \%)$. Then, $\mathrm{NaOH}(0.2 \%)$ was added at the end of the procedure. Water was discarded and triticale was blended in an Oster blender (model 972-55H) with additional water for $10 \mathrm{~min}$. Then the mixture passed through a U.S. Standard sieve $\mathrm{N}^{\circ} 35(500 \mu \mathrm{m})$ and later through an ASTM-E11 sieve $(125 \mu \mathrm{m})$. After $12 \mathrm{~h}$ of sedimentation, the supernatant was removed and the sample was centrifuged using a Weisser Hettich model Eba-85 for 15 min at $3000 \mathrm{rpm}$. This procedure was repeated. The obtained starch was dry-oven in Memmeret Labtec oven at $50{ }^{\circ} \mathrm{C}$ for $24 \mathrm{~h}$. Dry starch was blended again and finally, passed through the U.S. Standard sieve $\mathrm{N}^{\circ} 35$.

\section{Blends and films elaboration}

Thermoplastic starch (TPS) for each variety were elaborated for two starch/glycerol/water compositions: $50 / 25 / 25$ and 50/35/15. TPS was prepared using a Cooler Mixer (LABTECH Engineering Company LTD, model LMX10-S-VSFI) during $3.9 \mathrm{~min}$ at $2800 \mathrm{rpm}$. Starch films were elaborated by casting method. Also, specimens $(15 \times$ $2.5 \times 0.3 \mathrm{~cm}^{3}$ ) were hot pressed using a hydraulic press (LABTECH Engineering Company LTD, model LP20-B) at $120^{\circ} \mathrm{C}$ for $10 \mathrm{~min}$ and 80 bars for the mechanical tests.

\section{Granules morphology}

The morphology of the three varieties of triticale was studied using a scanning electron microscope ETEC Autoscan. Samples were gold coated by the use of a sputtering. Size of the starch granules was determined from analysis of the microphotographs obtained using the program Image J version 1.46 .

\section{Chemical analysis}

Triticale starch varieties were evaluated for humidity by oven-drying at $50{ }^{\circ} \mathrm{C}$ for $48 \mathrm{~h}$. The protein content was assessed using the Kjeldahl method (AOAC 2.057 method), lipids by the AOAC 7.062 method and total starch content of the flour by using the Megazyme Kit for total starch (AOAC 996.11). The amylose content was determined using the UNE-EN ISO 6647-1:2008 [19]. The data were reported as means $\pm \mathrm{SD}(\mathrm{n}=3)$.

\section{Thermo-rheological measurements}

The thermo-rheological measurements were performed by placing $30 \mathrm{~g}$ of the sample into the Mixolab ${ }^{\circledR}$ bowl (Chopin Technologies, France) and then, mixing. Water for optimum consistency $(1.1 \mathrm{~N} \cdot \mathrm{m})$ was $65 \%$. The mixing speed was $80 \mathrm{rpm}$. The $1^{\text {st }}$ stage corresponded to the initial mixing for $8 \mathrm{~min}$ at $30{ }^{\circ} \mathrm{C}$. Temperature was increased at $4{ }^{\circ} \mathrm{C} / \mathrm{min}$ from $30{ }^{\circ} \mathrm{C}$ to $60{ }^{\circ} \mathrm{C}\left(2^{\text {nd }}\right.$ stage $)$. In the $3^{\text {rd }}$ stage, the temperature was increased from $60{ }^{\circ} \mathrm{C}$ to $90{ }^{\circ} \mathrm{C}$. Then, a holding period of $7 \mathrm{~min}$ at $90{ }^{\circ} \mathrm{C}$ was set $\left(4^{\text {th }}\right.$ stage $)$, followed by a temperature decrease of $4{ }^{\circ} \mathrm{C} / \mathrm{min}$ until $50{ }^{\circ} \mathrm{C}$, and $5 \mathrm{~min}$ holding time until the $5^{\text {th }}$ stage. Total time analysis was $45 \mathrm{~min}$. Each analysis was conducted in duplicate.

\section{Mechanical tests}

Specimens of the blends were tested according to ASTM D638 using a crosshead speed of $10 \mathrm{~mm} / \mathrm{min}$ at room temperature using a Karg Industrie Technik Universal testing machine, Smar Tens 005 model.

\section{Results and discussion}

\section{Granules morphology}

From Figure 1 the morphology of Faraón, Aguacero and Peteroa starch granules is observed, respectively. The micrographs of Faraón triticale (Figure 1a) shows small spherical and large oval granules. The average particle size diameter was $9 \pm 2 \mu \mathrm{m}$. Figure $1 \mathrm{~b}$ ) shows microphotographs of Aguacero triticale starch. Large granules with mostly oval shape and smooth surface were observed. The average diameter was $16 \pm 2 \mu \mathrm{m}$. Finally, for Peteroa starch (Figure 1c), granules with uniform size and shape distribution with large granules are seen. Average diameter size was $14 \pm 1 \mu \mathrm{m}$.

\section{Chemical analysis}

The results for the chemical analysis of the three triticale varieties showed a starch content of the flour of $74.0 \pm 2.0 \%, 70.3 \pm 1.1 \%$ and $74.0 \pm 1.6 \%$, for Aguacero, Faraón and Peteroa starches, respectively. Fraś et al. [20] reported that the starch content of eight Polish winter hexaploid triticale varieties flours ranging from 68.2 to $77.5 \%$. Values obtained for the three triticale varieties are within this range.

The moisture content was lower for Aguacero $(6.7 \pm 3.2 \%)$ followed by Peteroa $(9.2 \pm 4.3 \%)$ and Faraón $(11.7 \pm 3.8 \%)$ varieties compared with the value of $13.25 \pm 0.02 \%$ (for Buck TK 25 variety) obtained by Aguirre et al. [4]. 

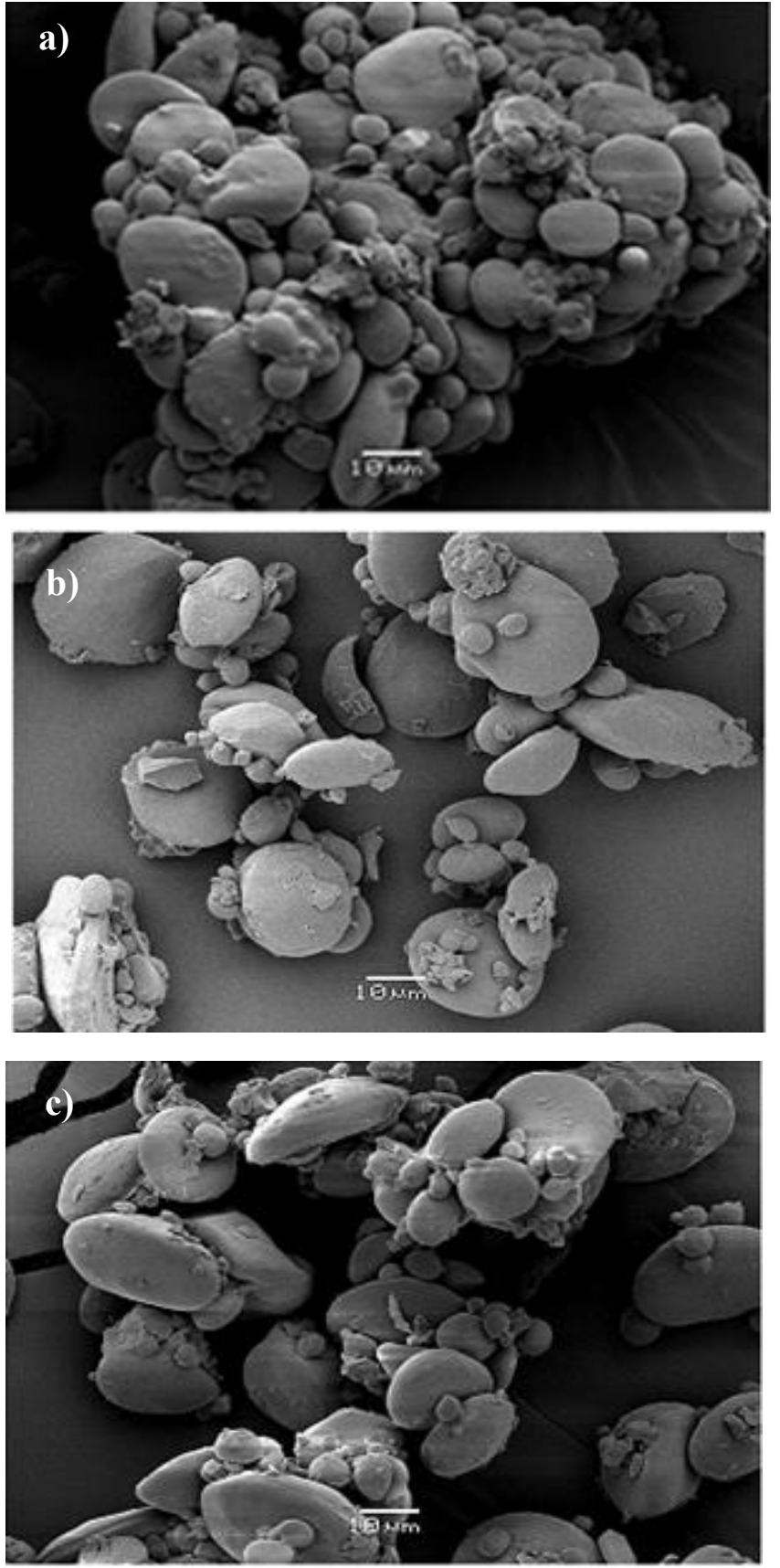

Figure 1. SEM micrographs of: a) Faraón, b) Aguacero and c) Peteroa triticale starch varieties

Protein content for the three varieties: Aguacero $(4.1 \pm 0.7 \%)$, Faraón $(5.2 \pm 0.2 \%)$ and Peteroa $(6.3 \pm 1.2 \%)$ was lower compared to the values between 9.8 and $13.9 \%$ reported by Fraś et al. [20].

Lipids content were within the range (1-2.4\%) reported by Rakha et al. [21] for Sweden triticale varieties, being $2.0 \pm 1.3 \%$ for Aguacero, $0.9 \pm 0.2 \%$ for Faraón and $1.2 \pm 0.5 \%$ for Peteroa varieties studied.

Also, the amylose content were within the range reported in the literature, 13.8-32.6 [22] for 33rd ITSN and 33rd ITYN triticale varieties. Obtained values in this work were $21.8 \pm 3.3 \%, 20.7 \pm 5.2 \%$ and $20.3 \pm 3.1 \%$ for Aguacero, Faraón and Peteroa starches, respectively.

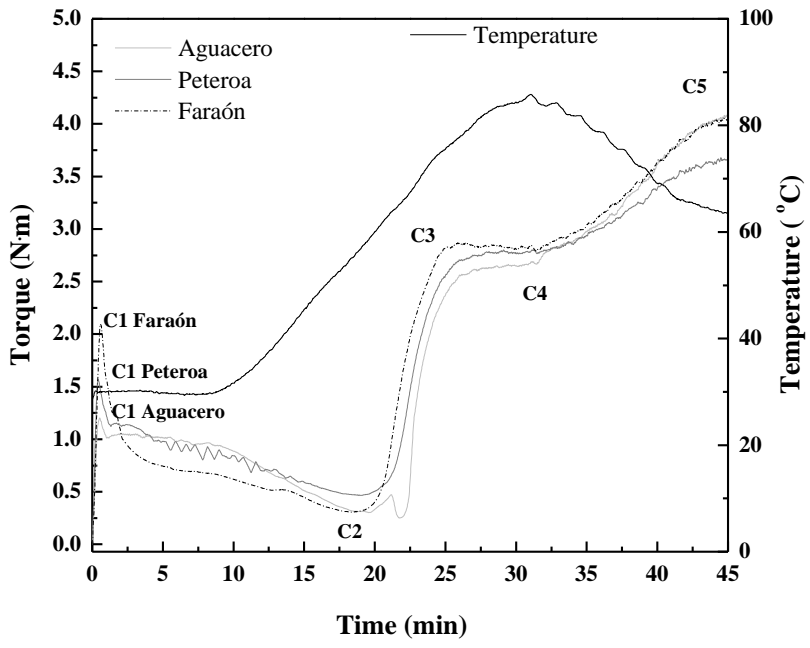

Figure 2. Mixolab ${ }^{\circledast}$ curve for Aguacero, Faraón and Peteroa starches

\section{Thermo-rheological measurements}

From Figure 2, Mixolab ${ }^{\circledR}$ curve for the three triticale starches varieties is shown. The main difference was found for $\mathrm{C} 1$ which is the initial maximum consistency $(\mathrm{N} \cdot \mathrm{m})$ use to determine the water absorption. This torque value was higher for Faraón $(2.10 \mathrm{~N} \cdot \mathrm{m})$, followed by Peteroa $(1.55 \mathrm{~N} \cdot \mathrm{m})$ and finally Aguacero $(1.20 \mathrm{~N} \cdot \mathrm{m})$. Flours with smaller particle size showed higher water absorption [23]. Faraón had the smaller granule size (see Figure 1) and the highest moisture content $(11.7 \pm 3.8 \%)$ in agreement with the results for $\mathrm{C} 1$ values shown in Figure 2. On the other hand, the protein weakening range $(\mathrm{C} 2-\mathrm{C} 1)$, the $3^{\text {rd }}$ and $4^{\text {th }}$ stages (swelling and gelatinization) and the $5^{\text {th }}$ stage of retrogradation were similar for the three starches. The gelatinization temperature obtained were $82.2{ }^{\circ} \mathrm{C}$ for Faraón starch, followed by Peteroa $\left(72.0^{\circ} \mathrm{C}\right)$ and finally Aguacero $\left(65.6^{\circ} \mathrm{C}\right)$. Faraón starch showed a higher gelatinization temperature compared to the other starches. Gelatinization temperature is higher and had a broader range for starches with smaller granule size compared to starches with larger granule size. [24].

\section{Mechanical tests}

From Table 1, the mechanical properties of TPS starch films are shown. The main factors evaluated were the starch type and the concentration of plasticizer (glycerol and water) for the different compositions of starch/glycerol/water $50 / 25 / 25$ and 50/35/15.

Table 1. Mechanical properties of TPS starch films

\begin{tabular}{ccccc}
\hline Variety Composition & $\begin{array}{c}\mathbf{E} \\
(\mathrm{MPa})\end{array}$ & $\begin{array}{c}\boldsymbol{\sigma}_{\boldsymbol{\beta}} \\
(\mathrm{MPa})\end{array}$ & $\begin{array}{c}\boldsymbol{\varepsilon}_{\boldsymbol{\beta}} \\
(\%)\end{array}$ \\
\hline Aguacero & $50 / 25 / 25$ & $1.54 \pm 1.12$ & $0.04 \pm 0.01$ & $36.35 \pm 14.41$ \\
Aguacero & $50 / 35 / 15$ & $0.54 \pm 0.42^{\dagger}$ & $0.03 \pm 0.01$ & $41.21 \pm 8.84$ \\
Faraón & $50 / 25 / 25$ & $1.90 \pm 1.09$ & $0.04 \pm 0.02$ & $34.69 \pm 6.93$ \\
Faraón & $50 / 35 / 15$ & $0.67 \pm 0.36^{\dagger}$ & $0.03 \pm 0.01$ & $37.94 \pm 8.64$ \\
Peteroa & $50 / 25 / 25$ & $1.16 \pm 0.38$ & $0.06 \pm 0.01$ & $39.34 \pm 7.39$ \\
Peteroa & $50 / 35 / 15$ & $0.37 \pm 0.31^{\dagger}$ & $0.02 \pm 0.02$ & $64.77 \pm 14.14$ \\
\hline
\end{tabular}

Values correspond to the average of three repetitions \pm the standard deviation. ${ }^{\dagger}$ Values are statistically different $(\mathrm{p}=0.05)$. 
In Table 1, it can be seen that the values of modulus of elasticity or Young's modulus (E), were higher for the films of composition $50 / 25 / 25$, as well as tensile strength at break $\left(\boldsymbol{\sigma}_{\beta}\right)$, while the percentage of elongation at break $\left(\boldsymbol{\varepsilon}_{\boldsymbol{\beta}}\right)$ was higher for the films of 50/35/15 composition. This can be attributed to the higher glycerol content of these films, which acts as a plasticizing agent. Therefore, when the content of glycerol in the films is increased, the tensile strength decreases and the elongation at break increases, which indicates that the increase in the amount of plasticizer reduces the intermolecular forces making the material more flexible [25].

Moreover, the final mechanical properties of the films are the result of interactions between the functional groups such as $\mathrm{C}-\mathrm{O}$ and $\mathrm{OH}$, present in starch, glycerol, and water and in some degree of miscibility or compatibility [26]. It can be seen, that for the same proportion 25/25 of glycerol/water in the films the Young's modulus is higher and the elongation at break is lower compared for the 35/15 glycerol/water proportion. It seems, that the plasticizing effect of glycerol is stronger than water. It has been found in the literature that starch and glycerol are partially miscible [27].

For the 50/25/25 composition, the film with the highest Young's modulus was for Faraón triticale starch $(1.90 \pm 1.09 \mathrm{MPa})$, followed by Aguacero $(1.54 \pm 1.12 \mathrm{MPa})$ and Peteroa $(1.16 \pm 0.38 \mathrm{MPa})$. Also, for the 50/35/15 composition, with values of $0.67 \pm 0.36 \mathrm{MPa}$, $0.54 \pm 0.42 \mathrm{MPa}$ and $0.37 \pm 0.31 \mathrm{MPa}$, for Faraón, Aguacero and Peteroa, respectively.

Additionally, the moisture content could generate a stiffening effect. From the chemical analysis, it was found, that the starch with the highest moisture content was the Faraón and from Table 1, it can be seen that the composition based on Faraón starch (50/25/25) had the highest Young's modulus. Then, the water associated to the starch molecules has a significant effect in the starch films mechanical properties [28].

On the other hand, for the most flexible film was for Peteroa composition 50/35/15 with $64.77 \pm 14.14 \%$ of elongation at break, followed by Aguacero (41.21 $\pm 8.84 \%$ ) and finally by Faraón $(37.94 \pm 8.64 \%)$. Same behavior was observed for the 50/25/25 composition (see Table 1). These results are in agreement with the behavior of mechanical properties in which the samples with lower Young's modulus had the higher elongation at break and vice-versa [25].

Related to particle size, it was observed that for the starch having the smaller granule size which corresponds to Faraón, had a higher Young's modulus and lowest elongation at break. This is because for a smaller size, there is an increase in the surface-to-area contact having a more stiffening effect [29].

\section{Conclusions}

A complete physico-chemical and thermo-rheological characterization of three varieties of triticale starch was achieved by using chemical analysis and Mixolab ${ }^{\circledR}$. In accordance to SEM observations, a more homogeneous grain size distribution was observed for Peteroa and Aguacero varieties compared to Faraón. Differences in gelatinization temperature were found for the starches. From the mechanical tests, the film with the highest Young's modulus was for Faraón 50/25/25 composition and the highest elongation at break was observed for Peteroa 50/35/15 composition. Triticale could be considered as a new source for thermoplastic biodegradable polymeric films with potential applications in packaging. However, TPS alone, does not have enough mechanical properties. Therefore, it should be used in compounds-based biodegradable polymer matrices.

\section{Acknowledgments}

Thanks to INIA-Quilamapu, Chile for Triticale starch sample. Also, the authors would like to thank to Eng. Rodrigo Jeria from Granotec Chile for Mixolab ${ }^{\circledR}$ characterization.

\section{References}

[1]. M. González-Petit, Z. Correa, M.A. Sabino, J. Polym. Environ. 23, 11 (2015).

[2]. L. Amagliani, J. O’Regan, A. Kelly, J. O’Mahony, J. Cereal Sci. 70, 291(2016).

[3]. M. Mellado, I. Matus, R. Madariaga, Boletín INIA 183, 1 (2008).

[4]. A. Aguirre, R. Borneo, A. León, LWT-Food Sci. Technol. 44, $1853(2011)$.

[5]. Z. Correa-Pacheco, A. Cruz-Orea, J. Jiménez-Pérez, S. Solorzano-Ojeda, C. Tramón-Pregnan, Int. J. Thermophys. 36, 873 (2015).

[6]. M. Schmiele, M. Ferrari, M. Pedrosa, Y. Kil, LWT-Food Sci. Technol. 76, 259 (2017).

[7]. C. Rosell, E. Santos, C. Collar, Eur. Food Res. Technol. 231. $\underline{535(2010)}$.

[8]. I. Švec, M. Hrušková, LWT-Food Sci. Technol. 60, 623 (2015). [9]. M. Fabra, M. Martínez-Sanz, L. Gómez-Mascaraque, R. Gavara, A. López-Rubio, Carbohyd. Polym. 186, 184 (2018).

[10]. S. Malmir, B. Montero, M. Rico, L. Barral, R. Bouza, Y. Farrag, Carbohyd. Polym. 194, 357 (2018).

[11]. J. Colivet, R. Calvalho, Ind. Crop Prod. 95, 599 (2017).

[12]. M. Ansorena, F. Zubeldía, M. Marcovich, LWT-Food Sci. Technol. 69, 47 (2016).

[13]. Y. García-Tejada, C. López-González, J. Pérez-Orozco, R. Rendón-Villalobos, A. Jiménez-Pérez, E. Flores-Huicochea, J. Solorza-Feria, C. Andrea Bastida, LWT-Food Sci. Technol. 54, 447 (2013).

[14]. J. Prakash Maran, V. Sivakumar, R. Sridhar, V. Prince Inmanuel, Ind. Crop Prod. 42, 159 (2013).

[15]. A. Nawab, F. Alam, M. Haq, Z. Lufti, A. Hasnain, Int. J. Biol. Macromol. 98, 869 (2017).

[16]. B. Murray, D. Gross, T. Fox, T., Starch Manufacturing: A Profile. Final Report. Research Triangle Institute, North Carolina (1994).

[17]. S. Badui Dergal, "Química de los alimentos" (Pearson, México, 2006) pp. 29-108.

[18]. C. Henríquez, B. Escobar, F. Figuerola, I. Chiffelle, H. Speisky, A. Estévez, Food Chem. 107, 592 (2008).

[19]. AOAC 2057, AOAC 7.062 and AOAC 996.11. 1990. Association of Official Analytical Chemists (AOAC), Official Methods of the Association Official Analytical Chemists.

[20]. A. Frás, K. Gołębiewska, D. Gołębiewski, D. Mańkowski, D. Boros, P. Szecówka, J. Cereal Sci. 71, 66 (2016). 
[21]. A. Rakha, P. Åman, R. Andersson, J. Cereal Sci. 54, 324 (2011).

[22]. A. Dennet, P. Schofield, J. Roake, N. Howes, J. Chin, J. Cereal Sci. 49, 393 (2009).

[23]. R. Moreira, F. Chenlo, S. Arufe, S. Rubinos, J. Food Sci. Technol. 52, 7954 (2015).

[24]. G. Rokey, Troubleshooting in "Advances in Food Extrusion Technology", M. Maskan and A. Altan (Eds.), (CRC Press, USA, 2016) pp. 355-382.
[25]. M. Sanyang, S. Sapuan, M. Jawaid, Mo. Ishak, J. Sahari, Polymers 7, 1106 (2015).

[26]. E. Basiak, A. Lenart, F. Debeaufort, Polymers 10, 1 (2018).

[27]. P. Ramsamy, Ionics 18, 413 (2012).

[28]. Z. Ping, Q. Nguyen, S. Chen, J. Zhou, Y. Ding, Polymer 42, $8461(2001)$.

[29]. O. Odusanya, D. Manan, U. Ishiaku, B. Azemi, J. Appl. Polym. Sci. 87, 877 (2003).

(C) 2019 by the authors; licensee SMCTSM, Mexico. This article is an open access article distributed under the terms and conditions of the Creative Commons Attribution license (http://creativecommons.org/licenses/by/4.0/). 